\title{
Sanjad-Sakati syndrome/Kenny- Caffey syndrome type 1: a study of 21 cases in Kuwait
}

K. K. Naguib, ${ }^{1}$ S.A. Gouda, ${ }^{1}$ A. Elshafey, ${ }^{1}$ F. Mohammed, ${ }^{2}$ L. Bastaki, ${ }^{1}$ A. S. Azab ${ }^{3}$ and S.A. Alawadi ${ }^{1}$

$$
\begin{aligned}
& \text { النمط الأول من متلازمة سنجد - سَقَطي: دراسة } 21 \text { حالة في الكويت }
\end{aligned}
$$

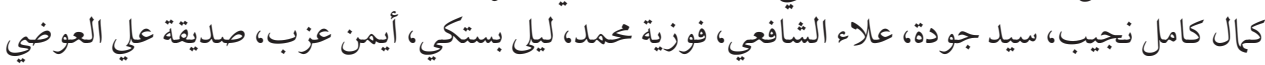

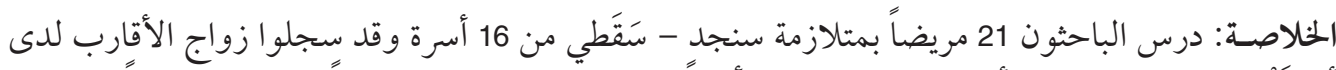

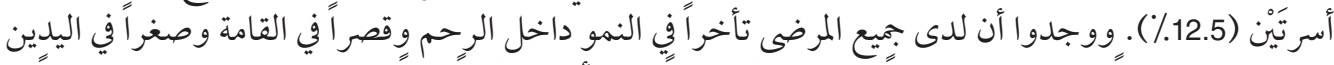

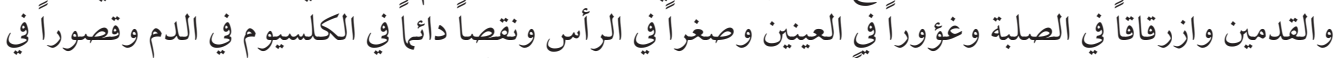

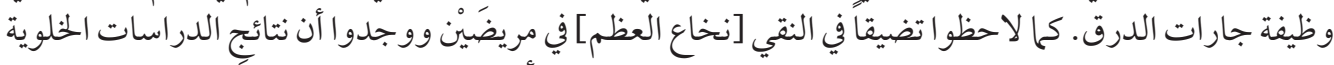

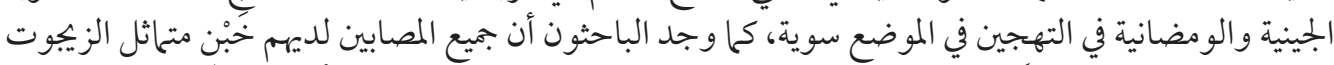

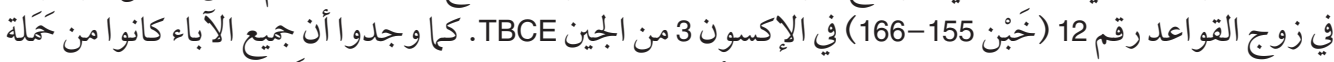

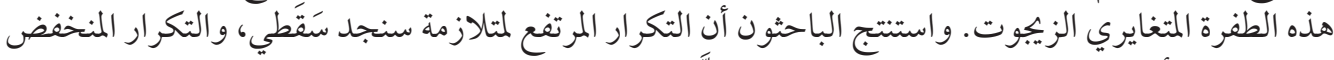

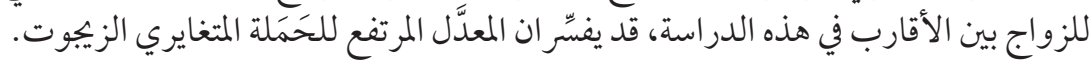

ABSTRACT We studied 21 patients with Sanjad-Sakati syndrome (SSS) from 16 families. Parental consanguinity was recorded in 2 families (12.5\%). All patients had severe intrauterine growth retardation, short stature, small hands and feet, blue sclera, deep-set eyes, microcephaly, persistent hypocalcaemia and hypoparathyroidism. Medullary stenosis was detected in 2 patients. Cytogenetic and fluorescent in situ hybridization studies were normal. All affected persons had homozygous deletion of $12 \mathrm{bp}$ (155-166del) in exon 3 of the TBCE gene. All of the parents were heterozygous carriers of this mutation. The high frequency of SSS and low frequency of consanguineous marriages in this study may reflect a high rate of heterozygous carriers.

Syndrome de Sanjad-Sakati et syndrome de Kenny-Caffey de type 1 : étude de 21 cas au Koweït RÉSUMÉ Nous avons étudié le cas de 21 sujets atteints du syndrome de Sanjad-Sakati (SSS) dans 16 familles. Une consanguinité parentale a été relevée dans deux familles $(12,5 \%)$. Tous les patients présentaient un grave retard de croissance intra-utérin, une petite taille, des petites mains et des petits pieds, une sclérotique bleue, des yeux enfoncés, une microcéphalie, une hypocalcémie persistante et une hypoparathyroïdie. Une sténose médullaire a été détectée chez deux sujets. Les études cytogénétiques et FISH (hybridation fluorescente in situ) étaient normales. Toutes les personnes touchées présentaient une délétion homozygote de 12 bp (155-166 del) dans l'exon 3 du gène TBCE. Tous les parents étaient porteurs hétérozygotes de cette mutation. La fréquence élevée de SSS et faible de mariages consanguins dans cette étude peut s'expliquer par un taux élevé de porteurs hétérozygotes.

\footnotetext{
${ }^{1}$ Kuwait Medical Genetic Centre; ${ }^{3}$ Department of Paediatrics, Adan Hospital, Ministry of Health, Kuwait (Correspondence to K.K. Naguib: naguibkk@yahoo.com).

${ }^{2}$ Department of Medical Laboratory Sciences, Kuwait University, Kuwait.

Received: 29/03/06; accepted: 17/09/06
}

المجلة الصحية لشرق المتوسط، منظمة الصحة العالمية، المجلد الخامس عشر، العدد Y، 9 ·. 


\section{Introduction}

Sanjad-Sakati syndrome (SSS; MIM 241410) [hypoparathyroidism-retardationdysmorphism (HRD; OMIM 241410)] is an autosomal recessive disorder first reported in 1988 [1] and confirmed by definitive report in 1991 [2]. It has been reported almost exclusively in the Middle Eastern population and is characterized by congenital hypoparathyroidism, retarded growth, mental retardation, seizures and a characteristic physiognomy [3]. The molecular pathology of this syndrome was shown to be due to mutations in the TBCE gene in chromosomal area $1 \mathrm{q} 42-\mathrm{q} 43[4,5]$. It is not uncommon in the Gulf area, especially Saudi Arabia and Kuwait: the incidence in Saudi Arabia varies from 1:40 000 to 1:100 000 live births [6]. In Kuwait, no precise data are available, although some reports have been published. Low incidence is expected (and recorded) because some authors consider it a variant of Kenny-Caffey syndrome type 1 (KCS type 1; OMIM 244460) [7-9].

Revision of the reports on patients in Kuwait identified as KCS type 1 showed that they fulfilled the criteria for SSS, and might be considered as such. Here we report a clinical and genetic study of 21 patients with SSS. The clinical picture, inheritance and molecular basis are discussed.

\section{Objectives}

We aimed to clarify the clinico-genetic spectrum of SSS and to detect/confirm the common mutation(s) responsible for this syndrome in Kuwait. We also wanted to clarify the diagnosis of KCS and SSS to determine whether they are a single entity.

\section{Methods}

All 21 Kuwaiti patients attending the Genetics Clinic in Kuwait Medical Genetic
Centre in the period 1993-2005 who were diagnosed with SSS underwent complete clinico-genetic evaluation. All patients were clinically assessed by one of the main authors (to avoid confusion and to maintain consistency). IQ/DQ assessment, skeletal survey, and relevant biochemical and echocardiographic studies were carried out. Cytogenetic analysis and fluorescent in situ hybridization (FISH) study for the CATCH 22 region were also performed.

\section{Mutation analysis of the TBCE gene}

Polymerase chain reaction/single-strand conformation polymorphism analysis and direct sequencing

Exons 2 (first coding exon), 3 (second coding exon) and 12 of the $T B C E$ gene were chosen for the initial screening as they were the only exons where mutations have been previously reported [5]. DNA was extracted from peripheral venous blood samples using the Wizard genomic DNA purification kit (Promega Corp., Wisconsin, United States of America) according to the manufacturer's protocol. Using Oligo software, version $3.4,3$ polymerase chain reaction (PCR) primer sets to amplify exons 2,3 , and 12 were designed (Table 1) and the $T B C E$ gene bank genomic sequence (accession: NT 004836).

Single-strand conformation polymorphism (SSCP) analysis was performed as follow: $5 \mu \mathrm{L}$ of the amplicons from each corresponding exon were mixed with equal volume of loading buffer ( $95 \%$ formamide, $10 \mathrm{mM} \mathrm{NaOH}, 0.05 \%$ xylene cyanol and $0.05 \%$ bromophenol blue), heat denatured at $96{ }^{\circ} \mathrm{C}$ for 3 minutes then quenched on ice for $\geq 5$ minutes. Samples were loaded into 0.5X MDE gel (Cambrex Bio Science, Maine, United States of America) with and without $10 \%$ glycerol in $0.6 \mathrm{X}$ trisborate-EDTA buffer. Gels were run at room temperature for 16 hours at $4 \mathrm{~W}$, then silver 
Table 1 Primers used to amplify exons 2, 3 and 12 and to sequence exon 3 of the TBCE gene

\begin{tabular}{|c|c|c|c|}
\hline Primer & Sequence & $\begin{array}{l}\text { PCR product } \\
\text { size (bp) }\end{array}$ & $\begin{array}{c}\text { Annealing } \\
\text { temperature }\left({ }^{\circ} \mathrm{C}\right)\end{array}$ \\
\hline TBCE_2F & 5'..AgATCTCATATTTTGGATTCTggA..3' & & \\
\hline TBCE_2R & 5'..CACACACACACACAATAATTgCT ..3' & 159 & 52 \\
\hline TBCE_3F & 5'..TTTggTTTTTCTTgTTCTgCT..3' & & \\
\hline TBCE_3R & 5'..gACCgTgCTgATTCATAATgA..3' & 137 & 51 \\
\hline TBCE3_(-)21M13 & 5'..(-)21M13-TTCCgCTgCAAATTggTATT..3' & & \\
\hline TBCE3_M13rev & 5'..M13rev-CATgAgCCAAACATTTCTTCC..3' & 307 & 54 \\
\hline TBCE_12F & 5'..CCgСТTTTСАТТТАТTТССТТ..3' & & \\
\hline TBCE_12R & 5'...TggCCTAAAATCATTTATTTTCT...3' & 248 & 54 \\
\hline$(-) 21 \mathrm{M} 13$ & 5'..TgTAAAACgACggCCAgT..3' & \multicolumn{2}{|c|}{ Sequencing primer } \\
\hline M13rev & 5'..CAggAAACAgCTATgACC..3' & \multicolumn{2}{|c|}{ Sequencing primer } \\
\hline
\end{tabular}

$P C R=$ polymerase chain reaction.

stained and photographed. When an electrophoresis mobility shift was observed, the corresponding PCR products were directly sequenced in the forward and reverse direction on a CEQ 8000 genetic analysis system (Beckmann Coulter, Inc., United States of America.) according to the manufacturer's protocol.

Agarose gel electrophoresis to screen for 12 bp deletion in exon 3

Screening for the 12 bp deletion (155-166 del) in exon 3 was performed for all patients and parents. PCR amplification products from exon 3 were resolved on $3 \%$ agarose (2 parts Nusieve, 1 part agarose) gel alongside $50 \mathrm{bp}$ DNA ladder. The product from the normal gene was expected to show a $137 \mathrm{bp}$ band. The product from the deleted gene was expected to give a 125 bp band. Heterozygous carriers were expected to show 2 PCR products of $137 \mathrm{bp}$ and $125 \mathrm{bp}$.

\section{Results}

Five of the 16 families had $>1$ affected offspring (31.3\%). Parental consanguinity was recorded in 2 families (12.5\%). Mean parental age when the children were born was 24.6 years for mothers and 29.4 years for fathers. Other findings are summarized in Table 2. The chromosomal study and the FISH study revealed normal findings in all cases. Molecular study using PCR/ SSCP analysis of exon 3 of the TBCE gene revealed band shift in all tested probands.

Table 2 Clinical picture of Sanjad-Sakati syndrome in 21 Kuwaiti patients

\begin{tabular}{lc}
\hline Feature & Frequency (\%) \\
\hline IUGR & 100 \\
Short stature & 100 \\
Microcephaly & 100 \\
Deep set eyes & 100 \\
Blue sclera & 100 \\
Large floppy ear lobule & 100 \\
Small hand & 100 \\
Small feet & 100 \\
Medullary stenosis & 10 \\
Hypocalcaemia & 100 \\
Hypoparathyroidism & 100 \\
Consanguinity & $12.5(2 / 16)^{\mathrm{a}}$ \\
Positive molecular findings & 100 \\
Parental heterozygosity & 100 \\
Mental retardation & $100(6 / 6)^{\mathrm{b}}$ \\
Affected sibs & $31.3(5 / 16)^{\mathrm{a}}$ \\
\hline${ }^{a}$ No. of families assessed $=16$. & \\
${ }^{\text {I }}$ (Q $70-89(6$ patients assessed). \\
IUGR = intra-uterine growth retardation.
\end{tabular}

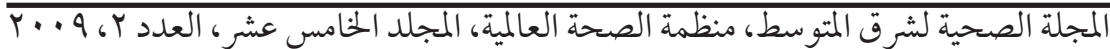




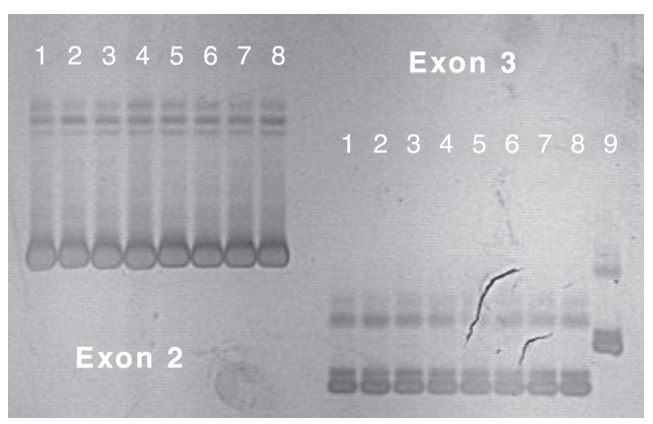

Figure 1 Single-strand conformation polymorphism analysis of exons 2 and 3 of the TBCE gene. Exon 3 analysis showed the same band shifts in all patient samples (lanes 1 to 8 ) in comparison with normal control (lane 9). No band shift in exon 2 analysis was detected.

No other shifts were detected from exons 2 and 12 (Figure 1).

Sequence analysis of exon 3 from both patients and normal controls revealed 12 bp deletions (155-166del) in all affected individuals. Sequence analysis of $T B C E$ gene exon 3 from a normal control gave: GAGGAAAGCATGATGGGAGCCACGAAGGGACTGTGTATTTTAAA and from a patient gave: GAGGAAAGCATGATGGGACTGTGTATTTTAAA (the deleted segment is underlined). The affected individual was homozygous with respect to the 155-166 del mutation. Screening for this deletion in the parents of affected individuals using PCR/agarose gel electrophoresis followed by sequencing revealed that both parents of all the patients were heterozygous carriers for this mutation (example shown in Figure 2).

\section{Discussion}

SSS is quite a frequent condition in Saudi Arabia and Kuwait and distributed in certain Bedouin tribes. To date, fewer than 15 reports have been published [10]. In Saudi Arabia, estimated incidence varies from $1: 40000$ to $1: 100000$ live births [6]. In Kuwait, no estimated incidence is reported for this syndrome. In the present report, we estimated the incidence of the syndrome at 7-18 per 100000 live births, based on the number of new cases and the total live births over the past 5 years (unpublished data). This is quite high and could be attributed to our recent awareness of SSS and/or to a high frequency of heterozygous carriers among the Kuwaiti population.

Revision of the published Kuwaiti reports revealed that some of the reported KCS type 1 patients fulfilled the criteria of SSS, and might be considered as SSS. To resolve this confusion, we revised all published papers on both syndromes. The

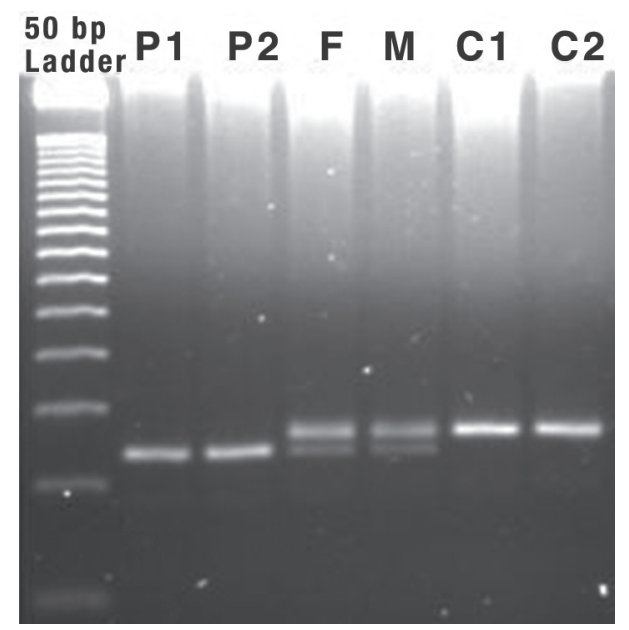

Figure 2 Gel electrophoresis of TBCE gene exon 3 polymerase chain reaction (PCR) products from 2 brothers (P1 and P2), their father (F), their mother (M) and 2 normal controls (C1 and C2). Patients showed homozygous shorter PCR products. The father and the mother showed 1 shorter and 1 normal sized (heterozygous) product compared to controls. 
confusion started when Franceschini et al. described female and male sibs, born of normal consanguineous parents, who had typical findings of KCS [6]. In this family, the female infant died at 10 days of age with generalized hypertonic seizures associated with hypocalcaemia. The later-born brother had neonatal hypoparathyroidism. Khan et al 1997 [11] again reported 16 affected children in 6 unrelated sibships, born to healthy, consanguineous parents of Bedouin ancestry. He suggested a recessive form of KCS. In fact the cardinal features, including microcephaly and psychomotor retardation of these patients fit with that of SSS. Evaluation of the patients' photographs and their phenotypes suggested a diagnosis of SSS rather than KCS type 1. Following this report, 2 other cases of KCS with deletion of $22 \mathrm{q}$ were reported, and it was suggested to extend the spectrum of CATCH 22 to accommodate KCS $[7,8]$. The clinical basis of these cases seems to point to SSS rather than KCS. In 1988, Diaz, Khan and Gelb [9], using 8 consanguineous Kuwaiti kindreds previously described by Khan et al 1997 [10], performed a genome-wide search for linkage to the gene causing the autosomal recessive form of KCS. They found a significant linkage to a locus situated at 1q42-q43. However, in 1999 Diaz et al. [12] suggested that both syndromes may be allelic.

More evidence that the syndromes may be the same was raised when Kelly et al. [4] reported linkage analysis in 3 consanguineous Saudi Arabian families with SSS syndrome to the same region as that shown by Diaz, Khan and Gelb [9] for KCS type 1. They suggested that these 2 syndromes were likely to be allelic disorders, if not the same condition.

Recently, Parvari et al. [5] demonstrated mutations in the TBCE gene in both autosomal recessive (type 1) KCS and SSS.
The gene $T B C E$ encodes a protein that participates in beta-tubulin folding [13]. All Middle Eastern patients showed a deletion of $12 \mathrm{bp}$ (155-166del) in exon 3 (second coding exon) of the $T B C E$ gene. In a Belgian family in which 2 siblings manifested features typical of SSS, 1 surviving sibling was compound heterozygous with respect to deletion of $2 \mathrm{bp}$ (66-67delAG) in exon 2 (first coding exon) with a nonsense mutation (1113T $\rightarrow$ A; CYS371TER) in exon 12 of the gene [5]. Accordingly, the confusion raised by some authors who refer to an autosomal recessive type of KCS has to be addressed. The similarity of the clinical picture and molecular basis of both syndromes strongly suggest the syndromes are identical/allelic.

Patients with SSS, typically present in the neonatal period with tetany, seizures or apnoea due to hypocalcaemia and recurrent infections probably due to immune defects $[14,15]$. However, the age at diagnosis of the previously reported cases ranged from 4 months to 12 years $[5,16]$. In the present study, most of the cases had been diagnosed during the neonatal period due to phenotypic picture, hypocalcaemia/seizures, or raised awareness of the syndrome among paediatricians and geneticists. Clinically, the syndrome has a wide phenotypic spectrum including deep set eyes, microcephaly, micrognathia, thin lips, beaked nose, depressed nasal bridge, external ear anomalies, small hands and feet, short stature and learning difficulties [17]. In addition, hypoparathyroidism, and hypocalcaemia are constant findings $[7,17,18]$. Small maxilla, enamel hypoplasia and severely decayed teeth were recorded recently [17].

All our patients showed the cardinal features described previously. These features resemble the features of a similar syndrome classified as autosomal dominant $\mathrm{KCS}$

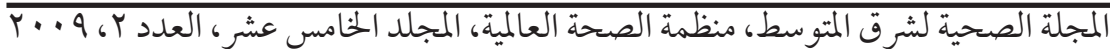


(KCS2; OMIM 127000) [8,17]. However, cortical thickening of the long bones with medullary stenosis, macrocephaly/normocephaly, normal mentality, cellular immune defects and absence of diploic space in the skull are additional features of KCS2 (Table 3) $[1,10,17]$. Accordingly, the differentiation between the 2 syndromes must be based on proper evaluation of the clinical picture and by biochemical, radiological and molecular diagnosis if possible.

Overlap with other syndromes such as CHARGE association, DiGeorge, velo- cardiofacial and CATCH 22 could be raised. The common findings are hypocalcaemia, growth retardations, hypoparathyroidism, immune deficiency, and abnormal facial features. However, the absence of characteristic phenotype of SSS, normal chromosomal complement and FISH studies and the characteristic molecular pathology will differentiate.

All patients in this study were homozygous for the deletion of 12 bp (155$166 \mathrm{del}$ ) in the $T B C E$ gene and their parents were heterozygous carriers for this mutation.

\begin{tabular}{|c|c|c|c|}
\hline Feature & $\begin{array}{l}\text { Sanjad-Sakati } \\
\text { syndrome }\end{array}$ & $\begin{array}{c}\text { Kenny-Caffey } \\
\text { syndrome, type } 1\end{array}$ & $\begin{array}{c}\text { Kenny-Caffey } \\
\text { syndrome, type } 2\end{array}$ \\
\hline Craniofacial & $\begin{array}{l}\text { Microcephaly; } \\
\text { micrognathia; deep-set } \\
\text { eyes; long philtrum; } \\
\text { posteriorly rotated ears }\end{array}$ & $\begin{array}{l}\text { Microcephaly; broad } \\
\text { cheeks; hypertelorism; } \\
\text { dental caries }\end{array}$ & $\begin{array}{l}\text { Macrocephaly; } \\
\text { nanophthalmos; corneal } \\
\text { and retinal calcification; } \\
\text { congenital cataracts }\end{array}$ \\
\hline Skeletal & $\begin{array}{l}\text { Delayed bone age; } \\
\text { patchy osteosclerosis; } \\
\text { small hands and feet }\end{array}$ & $\begin{array}{l}\text { Delayed bone age; } \\
\text { poorly ossified skull } \\
\text { bones; calvarial } \\
\text { osteosclerosis; } \\
\text { medullary stenosis of } \\
\text { tubular bones; small } \\
\text { hands and feet }\end{array}$ & $\begin{array}{l}\text { Osteosclerosis; } \\
\text { thickened cortex and } \\
\text { narrow marrow cavities } \\
\text { of long bones }\end{array}$ \\
\hline Mental & $\begin{array}{l}\text { Mental retardation (mild } \\
\text { to moderate) }\end{array}$ & $\begin{array}{l}\text { Mental retardation/ } \\
\text { normal mentality }\end{array}$ & Normal mentality \\
\hline Other & $\begin{array}{l}\text { Micropenis, } \\
\text { cryptorchidism, } \\
\text { ventricular dilatation }\end{array}$ & - & - \\
\hline Laboratory findings & $\begin{array}{l}\text { Hypocalcaemia; low } \\
\text { parathyroid hormone; } \\
\text { hyperphosphataemia; } \\
\text { normal cell mediated } \\
\text { immunity }\end{array}$ & $\begin{array}{l}\text { Hypocalcaemia low } \\
\text { parathyroid hormone; } \\
\text { low to low-normal } \\
\text { magnesium }\end{array}$ & $\begin{array}{l}\text { Transient } \\
\text { hypocalcaemia; low } \\
\text { parathyroid hormone } \\
\text { and iodine; transient } \\
\text { hypophosphataemia; } \\
\text { deficient T-cell function }\end{array}$ \\
\hline Molecular pathology & $\begin{array}{l}\text { Mutation in the tubulin- } \\
\text { specific chaperone } \mathrm{E} \\
\text { gene (TCBE) }\end{array}$ & $\begin{array}{l}\text { Mutation in the tubulin- } \\
\text { specific chaperone } \mathrm{E} \\
\text { gene (TCBE) }\end{array}$ & Unknown \\
\hline Inheritance & Autosomal recessive & Autosomal recessive & $\begin{array}{l}\text { Autosomal dominant/X- } \\
\text { linked }\end{array}$ \\
\hline
\end{tabular}

${ }^{a}$ Hypoparathyroidism-retardation-dysmorphism syndrome. 
This founder mutation is the only reported one, till now, in SSS patients from the Middle Eastern area [5]. Arabs in general are genetically diverse and have been admixed with many other populations from Asia, Europe and Africa. This founder mutation either started in the Arabs and then spread to the Middle Eastern area or vice versa. Extensive haplotype analysis around this mutation may clarify the situation.

In one of our families with 2 affected siblings, 1 sibling, a 2-year-old girl, had medullary stenosis while her 10-month-old brother showed osteosclerosis. This interfamilial variability raises the possibility that other modifying factors may affect $T B C E$ gene function and/or expression.

Affected siblings, mainly as products of phenotypically normal consanguineous parents, have been reported in previous reports [2,19-22]. Till now more than 26 patients have been reported, of whom more than half were familial $[10,19,20]$. In the present report, affected siblings were reported in 5 non-consanguineous families $(31.3 \%)$. Overall, consanguinity was found in only $12.5 \%$ of our patients, in spite of the high frequency of consanguineous marriage in
Kuwait (54.3\%) [21]. This could be due to chance occurrence or small sample size. Heterozygous carriers have to be assessed through a population-based study which would be of great help for future preventive measurements. The therapeutic options for SSS patients are limited to palliative therapy by correcting hypocalcaemia and treatment of infections [14,15]. However, prevention could be achieved through preimplantation genetic diagnosis (PGD) and carrier detection.

In conclusion, SSS is a common autosomal recessive disorder in the Gulf area. Clinically, it resembles in feature KCS type 2 . However, cortical thickening, medullary stenosis, macrocephaly/normocephaly, normal mentality, cellular immune defects and absence of the diploic space in the skull are additional features of KCS2. The confusion regarding the existence of an autosomal recessive type of KCS needs to be addressed and resolved in future reports. After the identification of the mutation(s) responsible, prevention of this syndrome may be achieved in future through preimplantation genetic diagnosis and carrier detection.

\section{References}

1. Sanjad S, Sakati N, Abu-Osba Y. Congenital hypoparathyroidism with dysmorphic features: a new syndrome. Pediatric research, 1988, 23:71A.

2. Sanjad SA et al. A new syndrome of congenital hypoparathyroidism, seizure, growth failure and dysmorphic features. Archives of disease in childhood, 1991, 66(11):193-6.

3. Al-Malik MI. The dentofacial features of Sanjad-Sakati syndrome: a case report. International journal of paediatric dentistry, 2004, 14:136-40.

4. Kelly TE et al. Confirmation of the assignment of the Sanjad-Sakati (congenital hy-
poparathyroidismsyndrome(OMIM241410) locus to chromosome 1q42-43. Journal of medical genetics, 2000, 37(1):63-4.

5. Parvari $R$ et al. Mutation of TBCE causes hypoparathyroidism-retardation-dysmorphism and autosomal recessive KennyCaffey syndrome. Nature genetics, 2002, 32:448-52.

6. Franceschini $P$ et al. Kenny-Caffey syndrome in two sibs born to consanguineous parents: evidence for an autosomal recessive variant. American journal of medical genetics, 1992, 42:112-6.

7. Sabry MA et al. Kenny-Caffey syndrome is part of the CATCH22 haploinsufficien-

المجلة الصحية لشرق المتوسط، منظمة الصحة العالمية، المجلد الخامس عشر، العدد ب، 9 ج. 
cy cluster. Journal of medical genetics, 1998, 35:31-6.

8. Sabry MA, Zaki M, Shaltout A. Genotypic/phenotypic heterogeneity of KennyCaffey syndrome. Journal of medical genetics, 1998, 35:1054-5.

9. Diaz GA, Khan KTS, Gelb BD. The autosomal recessive Kenny-Caffey syndrome locus maps to chromosome 1q42-q43. Genomics, 1998, 54:13-8.

10. OMIM Online Mendelian inheritance in man. Baltimore, Johns Hopkins University (http://www.ncbi.nlm.nih.gov/omim/, accessed 13 April 2009).

11. Khan KTS et al. Kenny-Caffey syndrome in six Bedouin sibships: autosomal recessive inheritance is confirmed. American journal of medical genetics, 1997, 69(2):126-32.

12. Diaz GA et al. Sanjad-Sakati and autosomal recessive Kenny-Caffey syndromes are allelic: evidence for an ancestral founder mutation and locus refinement. American journal of medical genetics, 1999, 85:48-52.

13. Tian $G$ et al. Pathway leading to correctly folded beta-tubulin. Cell, 1996, 86:287-96.

14. Hellani A et al. Pregnancy after preimplantation genetic diagnosis for SanjadSakati syndrome. Prenatal diagnosis, 2004, 24:302-6.

15. Hellani A et al. Pregnancy after preimplantation genetic diagnosis for ataxia telangiectasia. Molecular human reproduction, 2002, 8(8):785-8.
16. Marsden D, Nyhan WL, Sakati NO. Syndrome of hypoparathyroidism, growth hormone deficiency, and multiple minor anomalies. American journal of medical genetics, 1994, 52:334-8.

17. Parvari R et al. Homozygosity and linkage-disequilibrium mapping of the syndrome of congenital hypoparathyroidism, growth and mental retardation, and dysmorphism to a 1-cM interval on chromosome 1q42-43. American journal of human genetics, 1998 , 63:163-9.

18. Richardson RJ, Kirk JMW. Short stature, mental retardation and hypoparathyroidism: a new syndrome. Archives of disease in childhood, 1990, 65(10):1113-7.

19. Al Tawil $\mathrm{K}$ et al. Hypoparathyroidismretardation-dysmorphism (HRD) syndrome in triplets. American journal of medical genetics, 2005, 135:200-1.

20. Teebi AS. Hypoparathyroidism, retarded growth and development, and dysmorphism or Sanjad-Sakati syndrome: an Arab disease reminiscent of KennyCaffey syndrome. Journal of medical genetics, 2000, 37:145.

21. Al-Awadi $S$ et al. Consanguinity among the Kuwaiti population. Clinical geneticsm, 1985, 27:483-6.

22. Sabry MA et al. Kenny-Caffey syndrome: an Arab variant? Clinical genetics, 1999, 55:44-9. 